\title{
Mini Review: Exosomes from Discovery to Isolation
}

\author{
Sarah Renaud, Anthony Lefebvre, Olivier Moralès* and Nadira Delhem \\ CNRS UMR 8161 Equipe IRCV, Institut Pasteur de Lille, France \\ *Corresponding author: Olivier Moralès, CNRS UMR 8161 équipe IRCV, Institut Pasteur de Lille, France
}

\begin{tabular}{ll}
\hline ARTICLE INFO & ABSTRACT \\
$\begin{array}{l}\text { Received: } \\
\text { Published: February 18,2019 }\end{array}$ & $\begin{array}{l}\text { Since their discovery more than two decades ago, it has become increasingly clear that } \\
\text { exosomes play a crucial role in bodily homeostasis. In this mini-review we give an update } \\
\text { on exosome biogenesis, functions and compare isolation techniques based on previous } \\
\text { reports. }\end{array}$
\end{tabular}

Citation: Sarah Renaud, Anthony Lefebvre, Olivier Moralès, Nadira Delhem. Mini Review: Exosomes from Discovery to Isolation. Biomed J Sci \& Tech Res 15(2)2019. BJSTR. MS.ID.002683.

Keywords: Exosomes; Exosome Discovery; Exosome Isolation; Exosomes and Immunity; Extracellular Vesicles

\section{Discovery}

Exosomes were described for the first time over thirty years ago in 1983 [1]. Two papers, that were released within a week of each other, both showed that reticulocytes' transferrin receptors were externalised into the extracellular space [2,3]. Harding, Heuser and Stahl showed for the first time that a type of late endosome dubbed

"multivesicular endosomes" or MVEs was responsible for the recycling of the transferrin receptor. To their surprise, they found that the MVEs fused with the plasma membrane which led to the release of small vesicles, under $100 \mathrm{~nm}$ in diameter, found within MVEs [4] (Figure 1).
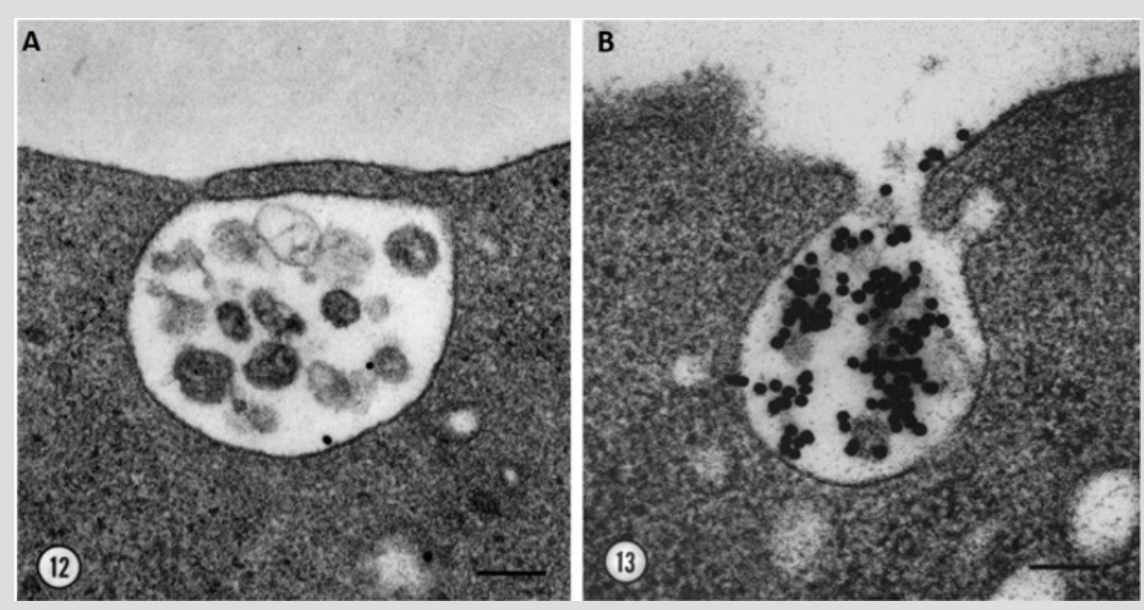

Figure 1: Exocytosis of MVEs and release of exosomes. Electron microscopy images of quick-frozen fixed reticulocytes labelled with AuTf showing A. fusion of MVE membrane with the plasma membrane B. and the release of transferrin receptor loaded exosomes into the extracellular space. Bar 100nm, Harding 1983.

At the same time, Pan and Johnstone proved in sheep reticulocytes that the transferrin receptor is externalized via vesicles. Although they did not visualize the phenomenon by electronic microscopy, they used anti-transferrin-receptor antibodies to follow the trafficking of the protein [3]. This discovery showed that plasma membrane recycling did not only occur for molecules bound to early endocytic compartments, as was the view at the time, but also molecules present on late endosomes such as MVEs.

Indeed, other molecules found deeper in the endocytic system were also recycled to the plasma membrane. For example, processed antigens seemed to be recycled from lysosomes to endosomes in order to bind to MHC-II. This complex is then expressed on the 
cell surface for T cell presentation [5]. Also, Lippincott-Schwartz and Fambrough found that the Lysosome-Associated Membrane Protein (LAM]P-1), then named LEP 100, was addresses to the plasma membrane [6].

Exosomes are secreted by virtually all cell types, but most notably by immune cells. Their immunomodulatory functions were first demonstrated by Raposo in B cells. They found that MHC-II-enriched MEVs released exosomes that could present MHCII-peptide complexes to $\mathrm{T}$ cells and induce an immune response [7]. Knowing this, other studies then looked at dendritic cells and found they could also secrete T-cell activating exosomes that are potent enough to eradicate tumours in an in vivo mouse model [810]. However, dendritic cell-Derived Exosomes (DEX) seem to be the only ones capable of activated naive $\mathrm{T}$ cells [11]. It was further described that naive CD4+ T cells need the presence of Antigen Presenting Cells (APCs) for this activation to take place, leading us to believe the exosomes are bound to the APCs membrane for this $[12,13]$. But a potent activation of naïve CD8+ T cell is found in the absence of APC but stimulated by IL-12 [14,15].

Moreover, macrophage-derived exosomes can also present antigens to $\mathrm{T}$ cells in a cell-surface-bound exosomes system [16]. It is noteworthy to mention that in this study, the cells were infected with Mycobacterium Tuberculosis (Mtb) and this alone enhances the production of exosomes. It has also been described in many virus-associated pathologies that exosomes favour the expansion of viral infection. For instance, HIV has been known to hijack the exosomal packing and/or release pathways to its advantage [17]. It has been suggested that HIV can charge its viral RNA into the infected cells' exosomes and intensify their release to facilitate the infection of healthy neighbouring cells.

\section{Biogenesis}

Exosomes differ to other secreted vesicles notably by their biogenesis. They arise in late endosomal compartment MEVs dubbed Multivesicular Bodies (MVBs) and when not-yet secreted are referred to as Intraluminal Vesicles (ILVs). Although unknown for a long time after their discovery, new light has been shed on exosome formation [18]. Molecules that are found on MVB membrane are either degraded after fusion of the MVB with lysosomes or secreted in the extracellular compartment after fusion with the plasma membrane [19,20] (Figure 2). In 2001, a paper by Katzmann showed that the sorting of ubiquitinylated MVB cargo was dependant on a $350 \mathrm{kDa}$ complex dubbed Endosomal Sorting Complex Required for Transport-I (ESCRT-I) [21,22]. Previous work identified ESCRT proteins as the major player in protein sorting of the vacuole in yeast [23]. The ESCRT machinery is made up of vacuolar protein sorting (Vps) subunits and 4 different protein complexes have been reported: ESCRT-0, I, II and III, but can also be associated to the AAA ATP Vps4 complex [24]. ESCRT is able to sequester and sort cargo and deform the MVEs membrane to bud inwards to generate MVBs [25].

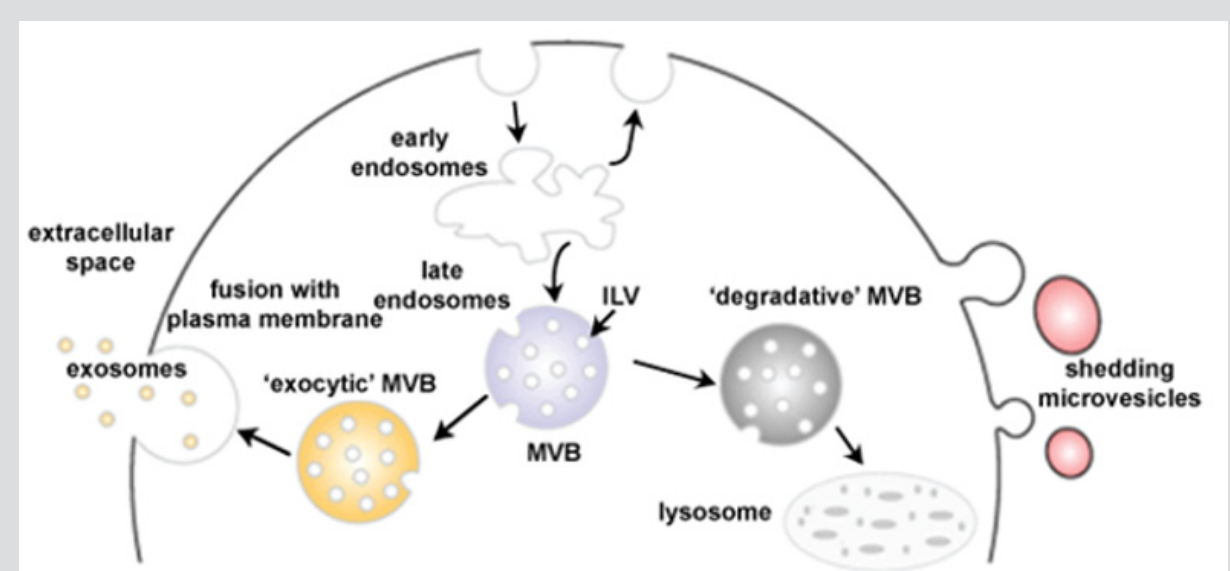

Figure 2: Schematic representation of exosome biogenesis. Early endosomes mature into late endosomes named MVBs in which ILVs have formed after inwards budding of the membrane. The MVBs have two possible fates: lysosome degradation by membrane fusion or release of the exosomes into the extracellular space by fusion with the plasma membrane (Adapted from Mathivanan 2010).

In the case of exosomes, elucidating the pathway leading to the fusion of the MVE membrane with the plasma membrane is key. Many proteins are involved in exosome biogenesis, from the inward budding of the MVE to the trafficking and subsequent fusion with the plasma membrane. The sphingolipid ceramide contributes to the transfer of specific exosome-associated cargo into the lumen of exosomes as well as their release. But has also been shown to trigger the curving of the vesicle membrane and subsequently bud $[26,27]$. It has also been suggested that calcium variations are important in the regulation of exosome biogenesis [28,29].

But other ESCRT-independent pathways of exosome biogenesis have been reported [30]. Ghossoub, found that the GTAPase ADP
Ribosylation Factor 6 (ARF6) and Phospholipase D2 (PLD2) control exosome biogenesis via an ESCRT-independent pathway involving ALG-2 interacting protein X (Alix) [31]. Blocking Alix did not lead to a decreased secretion of exosomes but rather a change in their composition. Meaning that Alix is more likely to be involved in cargo loading. However, silencing of STAM1 or TSG101 led to no or partial reduction of exosome secretion but mainly to a variation in protein composition [25,32]. Hoshino even showed that an increase in exosomes secretion after Hrs knockdown, a member of the ESCRT-0 complex, lead to a more invasiveness cancerous behaviour [33].

The release of exosomes into the extracellular domain depends on the fusion of the MVE membrane with the plasma membrane 
[34]. For this, MVE docking involves multiple GTP-binding proteins such as Rab4, Rab5, Rab11, Rab27, Rab35 and ARF that are all involved in exosome secretion [35-38]. Other regulators include the cortical actin regulator (cortactin) 39 and the fusion regulator synaptotagmin-7 [33]. It has recently been suggested that exosome biogenesis is not necessarily ESCRT-dependant or independent but rather that the two pathways could act synergistically or be compensatory [40]. For example, Alix is known as an ESCRT accessory protein but is also involved in ESCRT-independent pathways. And a third pathway of exosome biogenesis involving the tetraspanin CD63 has been described as both ESCRT-dependant and independent [41]. The idea is that the pathway of exosome biogenesis defines the nature, composition and content of the exosome.

\section{General Characteristics}

Exosomes are nanovesicles of $30-120 \mathrm{~nm}$ in diameter and are limited by a lipid bilayer. Unlike other Extracellular Vesicles (EVs), their origin is endocytic. As a result, exosomes are rich in endosome- associated proteins such as tetraspanins, which are often the gold standard for exosome identification. Although other molecules such as heat shock proteins and MHC Class I and II are recognised as "exosome markers" they have also been found on other nonexosomal EVs in a study carried out on DEXs [42]. Much work has gone into deciphering the protein, lipid and RNA content as well as the functions of exosomes. Databases such as EVpedia, Vesiclepdia and Exocarta all contribute to understanding this.

\section{Functions: Cell-to-Cell Communication}

Exosomes can be considered as "mini cells" in that they have the same membrane orientation as the cell itself, RNA can be contained in their lumen, they carry ligands, receptors and other various signalling molecules. Many ways of communication with the target cell have been described. Exosomes can release their cargo in the extracellular space near the target cell, they can also be endocytosed, fuse with the plasma membrane, work in a "kiss and run" manner or simply release their content into the cells' cytoplasm before targeting another cell [43] (Figure 3).

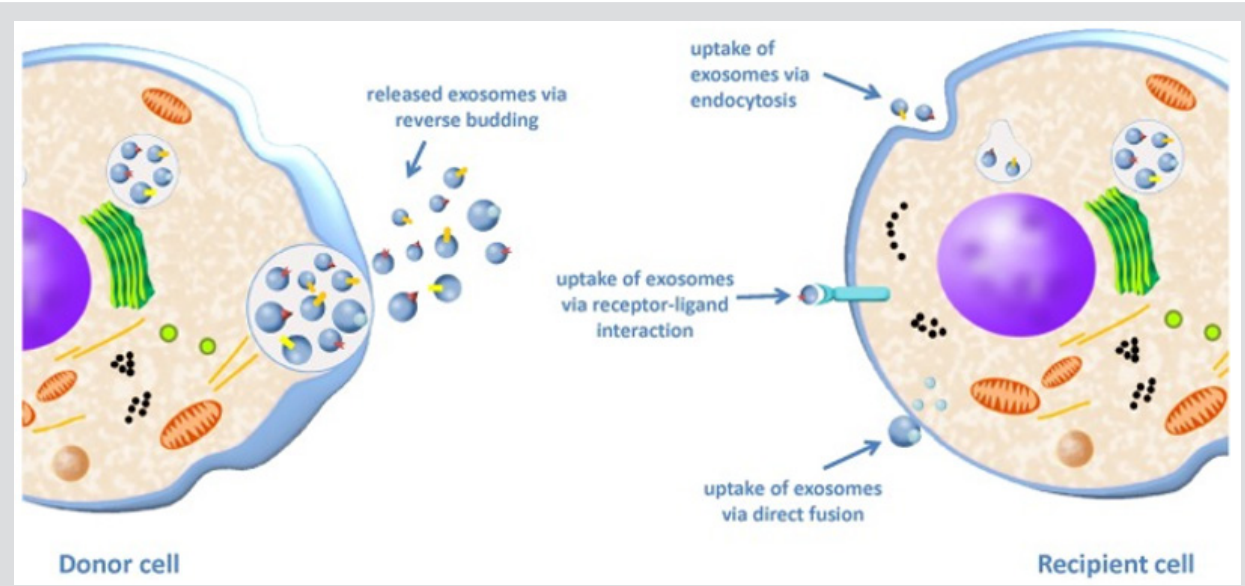

Figure 3: Exosome uptake from a donor cell to a recipient cell. The donor cell releases exosomes by fusion of the MVB membrane with the plasma membrane and subsequent secretion of ILVs into the extracellular space giving exosomes. The exosomes then interact with the recipient cell via three possible mechanisms: uptake by endocytosis, ligand/receptor interaction or by direct fusion of the exosome membrane with the plasma membrane [44].

Nevertheless, how the exosomes target recipient cells still remains largely unknown. We are only just scratching the surface but some studies are starting to decipher this [44-46]. Targeting could be led by either ligand-receptor affinity or by chemokines found on exosome. The latter would explain the recruitment of exosomes to more distant sites [47]. An interesting study by Heusermann also found that exosomes can bind to the active regions of filopodia and lamellipodia to then enter at endocytic hot spots of huh7 cells [48]. Moreover, this study demonstrated that exosomes taken up by the cell remain intact and are seemingly addressed to the Endoplasmic Reticulum (ER) where exosomal cargo is released before subsequent degradation by fusion with lysosomes. It has interestingly been discovered that siRNA and miRNA loading into RNA-silencing complex RISC takes place in the ER membrane [4951]. Thus, the authors put forward the hypothesis that this would allow an efficient entry of exosomal RNA into the cell's translational machinery.

The study of miRNAs has been gaining interest as they are now seen as a potential biomarker for many diseases, including cancer [52]. Part of circulating miRNAs are found in exosomes [53] although other studies have found that most of miRNAs are linked to the Ago2 protein [54]. It was shown that miRNA enrichment on exosomes can be regulated by the oncogene KRAS [55] and the ribonucleoprotein A2B1 (hnRNPA2B1) [56]. Regardless, exosomes do carry miRNAs and these have potent biological effects ranging from regulating translational activity to stability and localisation in recipient cells [57].

Exosomes have the advantage of being stable in the extracellular media notably due to their lipid bilayer, unlike free single molecules that are more exposed to degradation. Moreover, exosomes can travel virtually anywhere in the organism, even passing through the cells and nucleic membrane via microtubes [58] and nanotubes [59].

\section{Functions: Immune Modulation}

It is known that exosomes are secreted in larger amounts by immune cells compared to other cell types. Indeed, it was shown that exosomes alone can mediate antigen presentation and thus 
are capable of inducing a potent immune response [60,61] (Figure 4). MHCII $\alpha \beta$ dimers found on the plasma membrane of APCs can be incorporated into ILVs. After this, the charging of the antigen onto the MHCII happens within the MVBs [62]. And the subsequent release of exosomes charged with MHC II-antigen complexes into the extracellular media leads to the activation of naïve CD4 $\mathrm{T}$ cells [11]. It was shown that the major release of these exosomes happens at the immunological synapse site between APCs and T cells. DCs can also induce a $\mathrm{T}$ cell response by releasing exosomes that express co-stimulatory molecules CD80 and CD86 or mDC intercellular Adhesion molecule-1 (ICAM-1) [11,63,64]. A study by Qazi, showed in vivo that antigen-charged exosomes alone can induce a potent Th1 response [65]. Thus, exosomes secreted at the immunological synapse site allow inter-cellular communication between the different immune cell populations. Indeed, DEXs are taken up by $\mathrm{T}$ cells but $\mathrm{T}$ cells can also release exosomes, containing miRNAs and/or TCR, that can regulate gene expression and cell signalling of DCs $[66,67]$. Monteclavo also found that mice DCs could exchange functional miRNA via exosomes [68] (Figure 4).

Nevertheless, exosomes can also be used by regulatory immune cells to block the immune response and induce "infectious tolerance" [69]. In fact, mice Tregs were found to secrete exosomes that contain the miRNA let-7d that is taken up by CD4+ TNF $\gamma+$ Th1 cells and reduce their immunogenicity [70]. Other studies have shown that exosomes derived from mice Tregs can induce seemingly tolerogenic DCs via miR-150-155p and miR-142-143p [71]. However, the exosome-mediated tolerance of Tregs goes beyond miRNAs. Indeed, Okoye found that other factors such as non-coding RNA, chemokines, interleukins, collagen and matrix proteins found on mouse Treg-derived exosomes could induce immune tolerance (Figure 4). The immunosuppressive effect of Treg-derived exosomes seems so potent that it is even being considered as a possible therapeutic for autoimmune diseases and transplant patients [72,73].

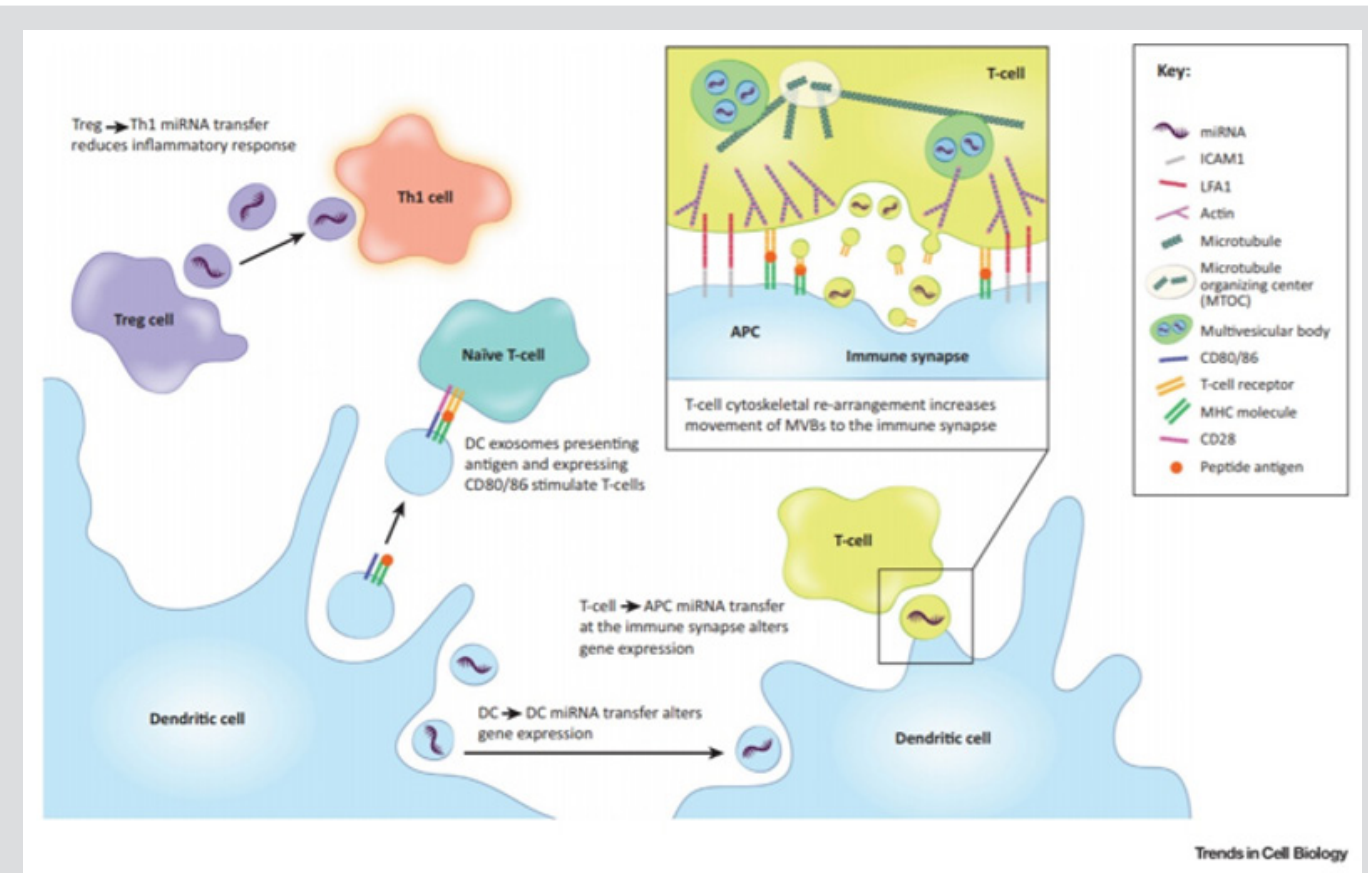

Figure 4: Immune modulation by exosomes. DEX carry miRNA, co-stimulatory molecules (CD80/86) and antigen charged MHC molecules that can be transferred to (i) naïve T cell to subsequently induce anti-tumour Th1 T cells, (ii) other DCs (iii) or $\mathrm{T}$ cells at the site of the immunological synapse to modulate the immune response. $\mathrm{T}$ cells can in return also secrete exosomes that will influence recipient DCs via miRNAs or the TCR that they carry. Exosomes derived from Tregs can block the immune response by hindering Th1 T cells via exosomal miRNA (Maas 2017).

Moreover, immunosuppressive Mesenchymal Stem Cells (MSCs) can use exosomes to inhibit macrophage response by impairing the recognition of Toll Like Receptors (TLR) [74] but also by triggering Treg differentiation after a TGF- $\beta$ and IFN $\gamma$ stimulation [75]. Other in vivo murine studies show that exosomes derived from tolerogenic DCs and Myeloid-Derived Suppressor Cells (MDSCs) favour Treg expansion and an inhibition of the Th1 response [76,77]. Although these results are very encouraging, we must bear in mind that most of these studies are carried out on mouse Treg-derived exosomes and further studies on human cells need to be done.

Thus, the use of exosomes in a systemic response such as the immune response makes perfect sense as they are highly itinerant and efficient. They most probably contribute to the fine-tuning of the immune balance in an energy-efficient and systemic manner.

\section{Isolation Methods}

Exosomes can be isolated via two main methods: a series of high speed centrifugations with the use of a gradient (sucrose or iodixanol flotation) [78] or by immunoaffinity-based capture. Both methods have proven highly efficient and with a good yield $[79,80]$. However, it must be pointed out that the immunoaffinitybased capture can only be used for characterisation of exosomes as functional tests would be hindered by the binding agent $[81,82]$. And ultracentrifugation could also damage the exosomes by the strong pressure the exosomes are put under [83]. Other methods have 
also been developed such as exosome precipitation using waterexcluding polymers (polyethylene glycol) $[84,85]$ or microfluidicsbased isolation [86,87]. The following table summarises the advantages and disadvantages of the above-mentioned techniques

Table 1: Comparison of isolation techniques [79].
(Table I). Each method has its pros and cons, but what is essential is to develop a technique that will lead to widespread use of exosome, hopefully for the clinic. This must be a cost-effective and easily mastered isolation method.

\begin{tabular}{|c|c|c|c|}
\hline $\begin{array}{l}\text { Isolation } \\
\text { Technique }\end{array}$ & Isolation principle & Potential Advantage & Potential Disadvantage \\
\hline $\begin{array}{l}\text { Ultracentrifugation- } \\
\text { based techniques }\end{array}$ & $\begin{array}{l}\text { Density. size, and shape based } \\
\text { sequential } \\
\text { separations of particulate } \\
\text { constituents and solutes }\end{array}$ & $\begin{array}{l}\text { Reduced cost and contamination } \\
\text { risks with separation } \\
\text { reagents. Large sample capacity } \\
\text { and yields large } \\
\text { amounts of exosomes }\end{array}$ & $\begin{array}{l}\text { High equipment cost, cumbersome., } \\
\text { long run time, and labour intensive } \\
\text { low } \\
\text { portability - not available at point- } \\
\text { of-care. high speed centrifugation } \\
\text { may } \\
\text { damage exosomes thus impeding } \\
\text { downstream analysis [85]. }\end{array}$ \\
\hline \multirow{2}{*}{$\begin{array}{l}\text { Size-based } \\
\text { techniques }\end{array}$} & \multirow{2}{*}{$\begin{array}{l}\text { Exosome isolation is exclusively } \\
\text { based on the size } \\
\text { difference between exosomes and } \\
\text { another particulate } \\
\text { constituents }\end{array}$} & $\begin{array}{l}\text { Ultrafiltration: Fast, does not } \\
\text { require special } \\
\text { equipment. good portability, direct } \\
\text { RNA extraction } \\
\text { possible. }\end{array}$ & $\begin{array}{l}\text { Ultrafiltration: low equipment } \\
\text { cost. moderate purity of isolated } \\
\text { exosomes. } \\
\text { shear stress induced deterioration. } \\
\text { possibility of clogging and vesicle } \\
\text { trapping. exosomes loss due to } \\
\text { attaching to the membranes. }\end{array}$ \\
\hline & & $\begin{array}{l}\text { SEC: high-purity exosomes. gravity } \\
\text { flow preserves the } \\
\text { integrity and biological activity: } \\
\text { superior } \\
\text { reproducibility. moderate sample } \\
\text { capacity. }\end{array}$ & $\begin{array}{l}\text { SEC: Moderate equipment cost. } \\
\text { requires dedicated equipment. not } \\
\text { trivial to } \\
\text { scale up. long run time. }\end{array}$ \\
\hline $\begin{array}{c}\text { Exosome } \\
\text { Precipitation }\end{array}$ & $\begin{array}{l}\text { Altering the solubility or } \\
\text { dispersibility or } \\
\text { exosomes by the use of water- } \\
\text { excluding polymers }\end{array}$ & $\begin{array}{l}\text { Easy to use. does not require } \\
\text { specialized equipment. } \\
\text { large and scalable sample capacity }\end{array}$ & $\begin{array}{l}\text { Co-precipitation of other non- } \\
\text { exosomal contaminants like } \\
\text { proteins and } \\
\text { polymeric materials. Long run time. } \\
\text { Requires pre-and post-cleanup. }\end{array}$ \\
\hline $\begin{array}{l}\text { Immunoaffinity } \\
\text { capture based } \\
\text { techniques }\end{array}$ & $\begin{array}{l}\text { Exosome fishing based on specific } \\
\text { interaction } \\
\text { between membrane-bound } \\
\text { antigens I receptors) of } \\
\text { exosomes and immobilized } \\
\text { antibodies I ligands) }\end{array}$ & $\begin{array}{l}\text { Excellent for the isolation of specific } \\
\text { exosomes. Highly } \\
\text { purified exosomes - much better } \\
\text { than those isolated by } \\
\text { other techniques. high possibility of } \\
\text { subtyping. }\end{array}$ & $\begin{array}{l}\text { High reagent cost. exosome tags } \\
\text { need to be established. low capacity } \\
\text { and low } \\
\text { yields. only works with cell-free } \\
\text { samples. minor heterogeneity } \\
\text { hampers } \\
\text { immune recognition. antigenic } \\
\text { epitope may be blocked or masked } \\
\text { [54]. }\end{array}$ \\
\hline $\begin{array}{c}\text { Microfluidics- } \\
\text { based techniques }\end{array}$ & $\begin{array}{l}\text { Microscale isolation based on a } \\
\text { variety of } \\
\text { properties of exosomes like } \\
\text { immunoaffinity. size. } \\
\text { and density. }\end{array}$ & $\begin{array}{l}\text { Fast. low cost. portable. easy } \\
\quad \text { automation and } \\
\text { integration. high portability. }\end{array}$ & $\begin{array}{l}\text { Lack of standardization and large- } \\
\text { scale tests on clinical samples. lack } \\
\text { of } \\
\text { method validation. moderate to low } \\
\text { sample capacity. }\end{array}$ \\
\hline
\end{tabular}

\section{References}

1. Harding CV, Heuser JE, Stahl PD (2013) Exosomes: Looking back three decades and into the future. J Cell Biol 200(4): 367-371.

2. Harding C, Stahl P (1983) Transferrin recycling in reticulocytes: $p H$ and iron are important determinants of ligand binding and processing. Biochem Biophys Res Commun 113: 650-658.

3. Pan BT, Johnstone RM (1983) Fate of the transferrin receptor during maturation of sheep reticulocytes in vitro: selective externalization of the receptor. Cell 33: 967-978.

4. Harding C, Heuser J, Stahl P (1983) Receptor-mediated endocytosis of transferrin and recycling of the transferrin receptor in rat reticulocytes. J Cell Biol 97: 329-339.
5. Harding CV, Collins DS, Slot JW, Geuze HJ, Unanue ER (1991) Liposomeencapsulated antigens are processed in lysosomes, recycled, and presented to T cells. Cell 64: 393-401.

6. Lippincott Schwartz J, Fambrough DM (1987) Cycling of the integral membrane glycoprotein, LEP100, between plasma membrane and lysosomes: kinetic and morphological analysis. Cell 49: 669-677.

7. Raposo G, Nijman HW, Stoorvogel W, Liejendekker R, Harding CV, et al. (1996) B lymphocytes secrete antigen-presenting vesicles. J Exp Med 183: $1161-1172$.

8. Théry C, Regnault A, Garin J, Wolfers J, Zitvogel L, et al. (1999) Molecular characterization of dendritic cell-derived exosomes. Selective accumulation of the heat shock protein hsc73. J Cell Biol 147: 599-610.

9. Théry C, Boussac M, Véron P, Ricciardi-Castagnoli P, Raposo G, et al. 
(2001) Proteomic Analysis of Dendritic Cell-Derived Exosomes: A Secreted Subcellular Compartment Distinct from Apoptotic Vesicles. J Immunol 166: 7309-7318.

10. Zitvogel L, Armelle Regnault, Anne Lozier, Joseph Wolfers, Caroline Flament, et al. (1998) Eradication of established murine tumors using a novel cell-free vaccine: dendritic cell-derived exosomes. Nat Med 4 : 594-600.

11. Théry C, Duban L, Segura E, Véron P, Lantz O, et al. (2002) Indirect activation of naïve $\mathrm{CD} 4^{+} \mathrm{T}$ cells by dendritic cell-derived exosomes. Nat. Immunol 3: 1156-1162.

12. Denzer K, van Eijk M, Kleijmeer MJ, Jakobson E, de Groot C, et al. (2000) Follicular Dendritic Cells Carry MHC Class II-Expressing Microvesicles at Their Surface. J Immunol 165: 1259-1265.

13. Vincent Schneider H, Stumptner-Cuvelette P, Lankar D, Pain S, Raposo G, et al. (2002) Exosomes bearing HLA-DR1 molecules need dendritic cells to efficiently stimulate specific T cells. Int Immunol 14: 713-722.

14. Li L, Jay SM, Wang Y, Wu SW, Xiao Z (2017) IL-12 stimulates CTLs to secrete exosomes capable of activating bystander $\mathrm{CD} 8^{+} \mathrm{T}$ cells. Sci Rep 7: 13365 .

15. Sprent J (2005) Direct stimulation of naïve T cells by antigen-presenting cell vesicles. Blood Cells Mol Dis 35: 17-20.

16. Ramachandra L, Qu Y, Wang Y, Lewis CJ, Cobb BA, et al. (2010) Mycobacterium tuberculosis Synergizes with ATP To Induce Release of Microvesicles and Exosomes Containing Major Histocompatibility Complex Class II Molecules Capable of Antigen Presentation. Infect Immun 78: 51-5125.

17. Ellwanger JH, Veit TD, Chies JAB (2017) Exosomes in HIV infection: A review and critical look. Infect Genet Evol J Mol Epidemiol Evol Genet Infect Dis 53: 146-154.

18. Hessvik NP, Llorente A (2018) Current knowledge on exosome biogenesis and release. Cell Mol Life Sci 75: 193-208.

19. Luzio JP, Rous BA, Bright NA, Pryor PR, Mullock BM, et al. (2000) Lysosome-endosome fusion and lysosome biogenesis. J Cell Sci 113(Pt 9): $1515-1524$

20. Mathivanan S, Ji H, Simpson RJ (2010) Exosomes: Extracellular organelles important in intercellular communication. J Proteomics 73: 1907-1920.

21. Katzmann DJ, Babst M, Emr SD (2001) Ubiquitin-dependent sorting into the multivesicular body pathway requires the function of a conserved endosomal protein sorting complex, ESCRT-I. Cell 106: 145-155.

22. Raiborg C, Stenmark H (2009) The ESCRT machinery in endosomal sorting of ubiquitylated membrane proteins. Nature 458: 445-452.

23. Babst M, Sato TK, Banta LM, Emr SD (1997) Endosomal transport function in yeast requires a novel AAA-type ATPase, Vps4p. EMBO J 16: 1820-1831.

24. Henne WM, Stenmark H, Emr SD (2013) Molecular mechanisms of the membrane sculpting ESCRT pathway. Cold Spring Harb. Perspect Biol $5(9)$.

25. Colombo M, Moita C, van Niel G, Kowal J, Vigneron J, et al. (2013) Analysis of ESCRT functions in exosome biogenesis, composition and secretion highlights the heterogeneity of extracellular vesicles. J Cell Sci 126: 5553-5565.

26. Kajimoto T, Okada T, Miya S, Zhang L, Nakamura S (2013) Ongoing activation of sphingosine 1-phosphate receptors mediates maturation of exosomal multivesicular endosomes. Nat Commun 4: 2712.

27. Trajkovic K, Okada T, Miya S, Zhang L, Nakamura S, et al. (2008) Ceramide triggers budding of exosome vesicles into multivesicular endosomes. Science 319: 1244-1247.

28. Baietti MF, Zhang Z, Mortier E, Melchior A, Degeest G, et al. (2012) Syndecan-syntenin-ALIX regulates the biogenesis of exosomes. Nat Cell Biol 14: 677-685.
29. Savina A, Fader CM, Damiani MT, Colombo MI (2005) Rab11 promotes docking and fusion of multivesicular bodies in a calcium-dependent manner. Traffic Cph Den 6: 131-143.

30. Stuffers S, Sem Wegner C, Stenmark H, Brech A (2009) Multivesicular endosome biogenesis in the absence of ESCRTs. Traffic Cph Den 10: 925937.

31. Ghossoub R, Lembo F, Rubio A, Gaillard CB, Bouchet J, et al. (2014) Syntenin-ALIX exosome biogenesis and budding into multivesicular bodies are controlled by ARF6 and PLD2. Nat Commun 5: 3477.

32. Tamai K, Tanaka N, Nakano T, Kakazu E, Kondo Y, et al. (2010) Exosome secretion of dendritic cells is regulated by Hrs, an ESCRT-0 protein. Biochem Biophys Res Commun 399: 384-390.

33. Hoshino D, Kirkbride KC, Costello K, Clark ES, Sinha S et al. (2013) Exosome secretion is enhanced by invadopodia and drives invasive behavior. Cell Rep 5(5): 1159-1168.

34. Colombo M, Raposo G, Théry C (2014) Biogenesis, secretion, and intercellular interactions of exosomes and other extracellular vesicles. Annu Rev Cell Dev Biol 30: 255-289.

35. Chieh Hsu, Yuichi Morohashi, Shin-ichiro Yoshimura, Natalia ManriqueHoyos, SangYong Jung, et al. (2010) Regulation of exosome secretion by Rab35 and its GTPase-activating proteins TBC1D10A-C. J Cell Biol 189: 223-232.

36. Ostrowski M, Carmo NB, Krumeich S, Fanget I, Raposo G, et al. (2010) Rab27a and Rab27b control different steps of the exosome secretion pathway. Nat Cell Biol 12: 19-30; 1-13.

37. Savina A, Vidal M, Colombo MI (2002) The exosome pathway in K562 cells is regulated by Rab11. J Cell Sci 115: 2505-2515.

38. Vidal MJ, Stahl PD (1993) The small GTP-binding proteins Rab4 and ARF are associated with released exosomes during reticulocyte maturation. Eur J Cell Biol 60: 261-267.

39. Sinha S, Hoshino D, Hong NH, Kirkbride KC, Grega-Larson NE, et al. (2016) Cortactin promotes exosome secretion by controlling branched actin dynamics. J Cell Biol 214: 197-213.

40. Maas SL N, Breakefield XO, Weaver AM (2017) Extracellular vesicles: Unique intercellular delivery vehicles. Trends Cell Biol 27: 172-188.

41. van Niel G (2011) The tetraspanin CD63 regulates ESCRT-independent and -dependent endosomal sorting during melanogenesis. Dev Cell 21: 708-721.

42. Kowal J, Arras G, Colombo M, Jouve M, Morath JP, et al. (2016) Proteomic comparison defines novel markers to characterize heterogeneous populations of extracellular vesicle subtypes. Proc Natl Acad Sci 113: E968-E977.

43. Mulcahy LA, Pink RC, Carter DR (2014) Routes and mechanisms of extracellular vesicle uptake. J Extracell Vesicles 3.

44. Steinbichler TB, Dudás J, Riechelmann H, Skvortsova II (2017) The role of exosomes in cancer metastasis. Semin Cancer Biol 44:170-181.

45. Costa-Silva B, Aiello NM, Ocean AJ, Singh S, Zhang H, et al. (2015) Pancreatic cancer exosomes initiate pre-metastatic niche formation in the liver. Nat Cell Biol 17: 816-826.

46. Hoshino A, Costa-Silva B, Shen TL, Rodrigues G, Hashimoto A, et al. (2015) Tumour exosome integrins determine organotropic metastasis. Nature 527: 329-335.

47. Mrizak D, Martin N, Barjon C, Jimenez-Pailhes AS, Mustapha R, et al. (2015) Effect of nasopharyngeal carcinoma-derived exosomes on human regulatory T cells. J Natl Cancer Inst 107: 363.

48. Heusermann W, Hean J, Trojer D, Steib E, von Bueren S, et al. (2016) Exosomes surf on filopodia to enter cells at endocytic hot spots, traffic within endosomes, and are targeted to the ER. J Cell Biol 213: 173-184.

49. Li S, Liu L, Zhuang X, Yu Y, Liu X, et al. (2013) MicroRNAs inhibit the translation of target mRNAs on the endoplasmic reticulum in Arabidopsis. Cell 153: 562-574. 
50. Reid DW, Nicchitta CV (2015) Diversity and selectivity in mRNA translation on the endoplasmic reticulum. Nat Rev Mol Cell Biol 16: $221-231$.

51. Stalder L, Heusermann W, Sokol L, Trojer D, Wirz J, et al. (2013) The rough endoplasmatic reticulum is a central nucleation site of siRNA-mediated RNA silencing. EMBO J 32: 1115-1127.

52. Johan Skog, Tom Wurdinger, Sjoerd van Rijn, Dimphna Meijer, Laura Gainche, et al. (2008) Glioblastoma microvesicles transport RNA and proteins that promote tumour growth and provide diagnostic biomarkers. Nat Cell Biol 10: 1470-1476.

53. Gallo A, Tandon M, Alevizos I, Illei GG (2012) The majority of microRNAs detectable in serum and saliva is concentrated in exosomes. PloS One 7: e30679.

54. Turchinovich A, Weiss L, Langheinz A, Burwinkel B (2011) Characterization of extracellular circulating microRNA. Nucleic Acids Res 39: 7223-7233.

55. Cha DJ, Franklin JL, Dou Y, Liu Q Higginbotham JN, et al. (2015) KRASdependent sorting of miRNA to exosomes. eLife 4: e07197.

56. Villarroya-Beltri C, Gutiérrez-Vázquez C, Sánchez-Cabo F, PérezHernández D, Vázquez J, et al. (2013) Sumoylated hnRNPA2B1 controls the sorting of miRNAs into exosomes through binding to specific motifs. Nat Commun 4: 2980.

57. Batagov AO, Kurochkin IV (2013) Exosomes secreted by human cells transport largely mRNA fragments that are enriched in the 3'-untranslated regions. Biol Direct 8: 12 .

58. Osswald M, Solecki G, Wick W, Winkler FA (2016) Malignant cellular network in gliomas: Potential clinical implications. Neuro-Oncol 18: 479-485.

59. Yamicia Connor, Sarah Tekleab, Shyama Nandakumar, Cherelle Walls, Yonatan Tekleab, et al. (2015) Physical nanoscale conduit-mediated communication between tumour cells and the endothelium modulates endothelial phenotype. Nat Commun 6: 8671.

60. Robbins PD, Morelli AE (2014) Regulation of immune responses by extracellular vesicles. Nat Rev Immunol 14: 195-208.

61. Roche PA, Furuta K (2015) The ins and outs of MHC class II-mediated antigen processing and presentation. Nat Rev Immunol 15: 203-216.

62. Buschow SI, Nolte-'t Hoen EN, van Niel G, Pols MS, ten Broeke T, et al. (2009) MHC II in dendritic cells is targeted to lysosomes or T cellinduced exosomes via distinct multivesicular body pathways. Traffic $\mathrm{Cph}$ Den 10: 1528-1542.

63. Segura E, Nicco C, Lombard B, Véron P, Raposo G, et al. (2005) ICAM-1 on exosomes from mature dendritic cells is critical for efficient naive T-cell priming. Blood 106: 216-223.

64. Segura E, Amigorena S, Théry C (2005) Mature dendritic cells secrete exosomes with strong ability to induce antigen-specific effector immune responses. Blood Cells Mol Dis 35: 89-93.

65. Qazi KR, Gehrmann U, Domange Jordö E, Karlsson MC, Gabrielsson S (2009) Antigen-loaded exosomes alone induce Th1-type memory through a B-cell-dependent mechanism. Blood 113: 2673-2683.

66. Choudhuri K, Llodrá J, Roth EW, Tsai J, Gordo S, et al. (2014) Polarized release of T-cell-receptor-enriched microvesicles at the immunological synapse. Nature 507: 118-123.

67. Mittelbrunn M, Gutiérrez-Vázquez C, Villarroya-Beltri C, González S Sánchez-Cabo F, et al. (2011) Unidirectional transfer of microRNAloaded exosomes from T cells to antigen-presenting cells. Nat Commu 2: 282 .

68. Montecalvo A, Larregina AT, Shufesky WJ, Stolz DB, Sullivan ML, et al. (2012) Mechanism of transfer of functional microRNAs between mouse dendritic cells via exosomes. Blood 119: 756-766.

69. Chatila TA, Williams CB (2014) Regulatory T cells: Exosomes deliver tolerance. Immunity 41: 3-5.

70. Okoye IS, Coomes SM, Pelly VS, Czieso S, Papayannopoulos V, et al. (2014) MicroRNA-containing T-regulatory-cell-derived exosomes suppress pathogenic T helper 1 cells. Immunity 41: 89-103.
71. Sim L Tung, Dominic A Boardman, Monica Sen, Marilena Letizia, Qi Peng, et al. (2018) Regulatory $T$ cell-derived extracellular vesicles modify dendritic cell function. Sci Rep 8: 6065.

72. Akansha Agarwal, Giorgia Fanelli, Marilena Letizia, Sim Lai Tung, Dominic Boardman, et al. (2014) Regulatory T cell-derived exosomes: possible therapeutic and diagnostic tools in transplantation. Front Immunol 5: 555.

73. Marta Monguió-Tortajada, Ricardo Lauzurica-Valdemoros, Francesc E Borràs (2014) Tolerance in organ transplantation: From conventional immunosuppression to extracellular vesicles. Front Immunol 5: 416.

74. Phinney DG, Di Giuseppe M, Njah J, Sala E, Shiva S, et al. (2015) Mesenchymal stem cells use extracellular vesicles to outsource mitophagy and shuttle microRNAs. Nat Commun 6: 8472.

75. Zhang Q Fu L, Liang Y, Guo Z, Wang L, et al. (2018) Exosomes originating from MSCs stimulated with TGF- $\beta$ and IFN $-\gamma$ promote Treg differentiation. J Cell Physiol 233: 6832-6840.

76. Wang Y, Tian J, Tang X, Rui K, Tian X, et al. (2016) Exosomes released by granulocytic myeloid-derived suppressor cells attenuate DSS-induced colitis in mice. Oncotarget 7: 15356-15368.

77. Yang X, Meng S, Jiang H, Chen T, Wu W (2010) Exosomes derived from interleukin-10-treated dendritic cells can inhibit trinitrobenzene sulfonic acid-induced rat colitis. Scand J Gastroenterol 45: 1168-1177.

78. Théry C, Amigorena S, Raposo G, Clayton A (2006) Isolation and characterization of exosomes from cell culture supernatants and biological fluids. Curr Protoc Cell Biol 3: 22.

79. Pin Li, Melisa Kaslan, Sze Han Lee, Justin Yao, Zhiqiang Gao (2017) Progress in exosome isolation techniques. Theranostics 7: 789-804.

80. Yamashita T, Takahashi Y, Nishikawa M, Takakura Y (2016) Effect of exosome isolation methods on physicochemical properties of exosomes and clearance of exosomes from the blood circulation. Eur J Pharm Biopharm 98: 1-8.

81. György B, Módos K, Pállinger E, Pálóczi K, Pásztói M, et al. (2011) Detection and isolation of cell-derived microparticles are compromised by protein complexes resulting from shared biophysical parameters. Blood 117: e39-e48.

82. Kalra H, Adda CG, Liem M, Ang CS, Mechler A, et al. (2013) Comparative proteomics evaluation of plasma exosome isolation techniques and assessment of the stability of exosomes in normal human blood plasma. Proteomics 13: 3354-3364.

83. Jeppesen DK, Hvam ML, Primdahl-Bengtson B, Boysen AT, et al. (2014) Comparative analysis of discrete exosome fractions obtained by differential centrifugation. J Extracell Vesicles 3: 25011.

84. Kim DK, Nishida H, An SY, Shetty AK, Bartosh TJ, et al. (2016) Chromatographically isolated CD63+CD81+ extracellular vesicles from mesenchymal stromal cells rescue cognitive impairments after TBI. Proc Natl Acad Sci U S A 113: 170-175.

85. Emily Zeringer, Timothy Barta, Mu Li and Alexander V Vlassov (2015) Strategies for isolation of exosomes. Cold Spring Harb Protoc 2015: 319323.

86. Davies RT, Kim J, Jang SC, Choi EJ, Gho YS, et al. (2012) Microfluidic filtration system to isolate extracellular vesicles from blood. Lab Chip 12: $5202-5210$.

87. Kyungheon Lee, Huilin Shao, Ralph Weissleder, Hakho Lee (2015) Acoustic purification of extracellular microvesicles. ACS Nano 9: 23212327. 


\section{ISSN: 2574-1241}

DOI: 10.26717/BJSTR.2019.15.002683

Olivier Moralès. Biomed J Sci \& Tech Res

(c) (i) This work is licensed under Creative

Submission Link: https://biomedres.us/submit-manuscript.php

$\begin{array}{ll}\text { BIOMEDICAL } & \text { Assets of Publishing with us } \\ \text { RESEARCHES } & \text { - Global archiving of articles } \\ & \text { - Immediate, unrestricted online access } \\ & \text { - Rigorous Peer Review Process } \\ \end{array}$

